\section{Antioxidant enzyme activity in germination of Dalbergia spruceana seeds under different temperatures}

\author{
Clenes Cunha Lima ${ }^{1 *}$, Ely Simone Cajueiro Gurgel ${ }^{2}$ (D) , Eduardo Euclydes \\ de Lima e Borges ${ }^{3}$
}

ABSTRACT: Antioxidant enzyme activity can be used to measure heat stress and predict the tolerance of a species to heat stress. This study investigated the effects of temperature on germination and antioxidant enzyme activity in Dalbergia spruceana Benth. seeds. Seeds were incubated at constant temperatures of $20,25,30,35$, and $40{ }^{\circ} \mathrm{C}$ for ten days; and germination percentage, germination speed index, antioxidant enzyme activity, and electrical conductivity were evaluated. Temperature affected the seed germination process but not antioxidant enzyme activity. Germination percentage and germination speed index were higher at 25 and $35{ }^{\circ} \mathrm{C}$ and lower at 20 and $40{ }^{\circ} \mathrm{C}$. Superoxide dismutase activity was not affected by temperature. Catalase and peroxidase activities were too low to be used as indicators of temperature stress. The pattern of increasing electrolyte leakage manifested a trend toward loss of cell membrane semipermeability at higher temperatures.

Index terms: heat stress, cell membranes, cell homeostasis, jacarandá-do-Pará.

Atividade de enzimas antioxidantes na germinação de sementes de Dalbergia spruceana sob diferentes temperaturas

RESUMO: O estresse causado por temperatura pode ser mensurado pela atividade de enzimas antioxidantes e predizer a tolerância das espécies ao estresse térmico. Este trabalho investigou os efeitos da temperatura na germinação e atividade de enzimas antioxidantes em sementes de Dalbergia spruceana Benth. As sementes foram incubadas a temperaturas constantes de $20,25,30,35$ e $40^{\circ} \mathrm{C}$ durante dez dias e avaliada a porcentagem de germinação, índice de velocidade de germinação, atividade de enzimas antioxidantes e condutividade elétrica. A temperatura afetou o processo germinativo das sementes, mas não a atividade das enzimas antioxidantes. Temperaturas entre 25 e $35^{\circ} \mathrm{C}$ proporcionam o máximo percentual e velocidade de germinação, enquanto 20 e $40{ }^{\circ} \mathrm{C}$ geram os menores valores. A atividade da SOD se mostra indiferente às variações da temperatura e os níveis de atividades da CAT e da POX não permitem estabelecê-las como indicadoras de estresse térmico. $O$ padrão crescente de vazamento de eletrólitos revelou tendência na perda da semipermeabilidade das membranas celulares, em temperaturas mais altas.

Termos para indexação: estresse térmico, membranas celulares, homeostase celular, jacarandá-do-Pará.
Journal of Seed Science, v.43, e202143006, 2021

http://dx.doi.org/10.1590/ 2317-1545v43244385

\author{
*Corresponding author \\ E-mail: clelimaflor@yahoo.com.br \\ Received: $10 / 7 / 2020$. \\ Accepted: 12/14/2020.
}

${ }^{1}$ Programa de Pós-graduação em Biodiversidade e Biotecnologia da Rede Bionorte - 66077-830, Belém, Pará, Brasil.

${ }^{2}$ Coordenação de Botânica, Museu Paraense Emilio Goeldi - 66077830, Belém, Pará, Brasil.

${ }^{3}$ Departamento de Engenharia Florestal, Universidade Federal de Viçosa (UFV) - 36570-900, Viçosa, MG, Brasil. 


\section{INTRODUCTION}

Temperature changes in the environment can be detected by plant cells, and specific pathways of biochemical and molecular responses are triggered due to these temperature changes (Ruelland and Zachowski, 2010). Incubating seeds at high temperatures, for example, induces oxidative stress, with an increase in the production and accumulation of reactive oxygen species (ROSs) (Matos et al., 2014), which induces a chain of metabolic events in the cell.

Although ROSs are essential at low concentrations during germination, they must be maintained under strict control by antioxidant systems, otherwise their accumulation leads to cell damage and metabolic disturbances (Bailly et al., 2008). Consequences of intoxication by ROS in seeds include biomolecular changes, loss of seed viability during storage (Bailly et al., 2008), reduction in ATP production (Matos et al., 2014), lipid peroxidation, and rupture of the cell membrane (Santos et al., 2017). Maintaining membrane integrity and fluidity is fundamental for species survival in the face of heat stress (Zheng et al., 2011).

Plants have developed a complex system of enzymatic and non-enzymatic antioxidant protection to neutralize the effects of ROSs in cells: superoxide dismutase (SOD), catalase (CAT), and peroxidase (POX), for example (Sharma et al., 2012; Matos et al., 2014). SOD, considered the first line of defense at cell level, acts in protection against the superoxide radical $\left(\mathrm{O}_{2}{ }^{-}\right)$, disproportionate it to hydrogen peroxide $\left(\mathrm{H}_{2} \mathrm{O}_{2}\right)$ and oxygen (Saisanthosh et al., 2018). $\mathrm{H}_{2} \mathrm{O}_{2}$ is detoxified into molecular oxygen and water by two different systems: the glutathione peroxidase system, which is the first line of defense against $\mathrm{H}_{2} \mathrm{O}_{2}$, or CAT and POX, which also act in reduction of hydrogen peroxide (Sharma et al., 2012; Matos et al., 2014).

$\mathrm{H}_{2} \mathrm{O}_{2}$ is a molecule that can cause extensive oxidative damage to seeds, especially considering that the mitochondria is one of the main sources of peroxide generation (Bailly et al., 2008; Matos et al., 2014). Identifying changes in the levels of peroxidase activities in response to variations in temperature is fundamental for drawing conclusions regarding protection mechanisms during germination of seeds under stress. Synchronized action of the antioxidant enzymes provides greater tolerance to stress through cell detoxification during germination of seeds under adverse temperature conditions. In Dalbergia nigra (Matos et al., 2014), Erythrina velutina (Ribeiro et al., 2014), and Melanoxylum brauna (Santos et al., 2017) seeds, antioxidant enzymatic changes were characterized as a defense mechanism favorable to germination.

Scientific parameters have not yet been established for Dalbergia spruceana Benth. (Fabaceae) seeds for identification of physiological responses during germination. D. spruceana is native to the north of South America (Colombia and Venezuela) and, in Brazil, it can be found in the states of Amazonas, Amapá, Acre, Rondônia, and Pará (Souza, 2012). It is commonly known as facheiro, jacarandá do Pará, and timbó pau, or Amazon rosewood (English), with economic potential from use of its wood in manufacture of furniture and decorative objects (Gonçalves et al., 2012; Souza, 2012). As it is a species of medium to rapid growth and is easily propagated, it is recommended for reforestation and forest restoration programs (Gama and Pinheiro, 2010).

Understanding the role of antioxidant enzymes under heat stress conditions during seed germination can be an important tool for predicting the tolerance ability of the species in environmental sustainability programs. Thus, the aim of this study was to investigate the responses of antioxidant enzyme activity during the germination of $D$. spruceana Benth. seeds under different temperatures.

\section{MATERIAL AND METHODS}

Fruit from D. spruceana was collected in the municipality of Canaã dos Carajás, Pará, Brazil $\left(06^{\circ} 23^{\prime} 04.55^{\prime \prime}\right.$ S, $49^{\circ} 50^{\prime} 59.6^{\prime \prime}$ W), in July 2019 from six trees approximately 100 meters distant from one another. Climate in the region is type Aw, as defined by Köppen, with mean annual rainfall of $2033 \mathrm{~mm}$ and minimum temperatures from 15.6 to $18.3^{\circ} \mathrm{C}$ and maximum temperatures from 34.3 to $38.1^{\circ} \mathrm{C}$ (Viana et al., 2016).

After processing the seeds, their moisture content was determined through the laboratory oven method at $105 \pm 3{ }^{\circ} \mathrm{C}$ 
for 24 hours, with five replications of twenty seeds each (Brasil, 2009). At approximately 8\% moisture content, the seeds were stored in plastic packaging and kept in the refrigerator $\left(5^{\circ} \mathrm{C}\right)$ for up to thirty days prior to performance of analyses.

Germination: conducted with five replications of twenty seeds each, which were immersed in $1 \% \operatorname{Captan}^{\circledR}$ solution for $60 \mathrm{~s}$ and then placed without washing in Petri dishes on two sheets of Germitest ${ }^{\circledR}$ type germination paper moistened with deionized water in the amount of 2.5 times the weight of the dry paper (Brasil, 2009). The dishes were kept in a biochemical oxygen demand (BOD) type germination chamber at the constant temperatures of $20,25,30,35$, and $40^{\circ} \mathrm{C}$ for ten days. The seeds were considered germinated when they had primary root length of $2 \mathrm{~mm}$. Daily counts were made and results were expressed in germination percentage (G\%) and germination speed index (GSI) (Maguire, 1962).

Electrical conductivity: conducted with three replications of 25 seeds each, previously weighed on an electronic precision balance $(0.001 \mathrm{~g}$ resolution) and then placed in plastic cups containing $100 \mathrm{~mL}$ of distilled water and kept in a BOD type germination chamber at the same temperatures used in the germination test. After $0,24,48,72$, and 96 hours, the electrical conductivity of the imbibition water was determined by a digital bench-top conductivity meter (Micronal model B330), and results were expressed in $\mu \mathrm{s} . \mathrm{cm}^{-1} \cdot \mathrm{g}^{-1}$ seed.

Enzyme activity: the seeds were placed at the temperatures as described for the germination test, and samples were taken every $24 \mathrm{~h}$, up to $96 \mathrm{~h}$. The crude enzyme extracts used for determinations of activity of superoxide dismutase (SOD), catalase (CAT), and peroxidase (POX) were obtained from the method described by Peixoto et al. (1999). The quantity of $0.2 \mathrm{~g}$ of embryo (cotyledon + embryonic axis) was macerated in liquid nitrogen, followed by addition of $2.0 \mathrm{~mL}$ of homogenization medium: $0.1 \mathrm{M}$ potassium phosphate buffer, $\mathrm{pH} 6.8,0.1 \mathrm{mM}$ ethylenediamine tetraacetic acid (EDTA), $1 \mathrm{mM}$ phenylmethylsulfonyl fluoride, and $1 \%$ polyvinylpolypyrrolidone $(\mathrm{w} / \mathrm{v})$. Centrifugation was then performed at $14,000 \mathrm{~g}$ for $20 \mathrm{~min}$ at $4{ }^{\circ} \mathrm{C}$.

Superoxide dismutase (SOD): $50 \mu \mathrm{L}$ of crude enzyme extract was added to $2.95 \mathrm{~mL}$ of reaction medium consisting of $50 \mathrm{mM}$ sodium phosphate buffer, $\mathrm{pH}$ 7.8, $13 \mathrm{mM}$ methionine, $75 \mu \mathrm{M}$ nitroblue tetrazolium (NBT), $0.1 \mathrm{mM}$ EDTA, and 2 $\mu \mathrm{M}$ riboflavin (Del Longo et al., 1993). The reaction was conducted at $25^{\circ} \mathrm{C}$ in a reaction chamber under lighting with a $15 \mathrm{~W}$ fluorescent bulb. After 5 min of exposure, lighting was interrupted and blue formazan produced by photoreduction of NBT was measured at $560 \mathrm{~nm}$ (Giannopolitis and Ries, 1977). The absorbance at $560 \mathrm{~nm}$ of a reaction medium exactly the same as the previous one but kept in the dark for an equal time was used as a control. A SOD unit was defined as the amount of enzyme necessary to inhibit photoreduction of NBT by 50\% (Beauchamp and Fridovich, 1971).

Catalase (CAT): determined by addition of $50 \mu \mathrm{L}$ of crude enzyme extract to $2.95 \mathrm{~mL}$ of reaction medium consisting of $100 \mathrm{mM}$ potassium phosphate buffer, $\mathrm{pH} 6.8$, and $12.5 \mathrm{mM} \mathrm{H}_{2} \mathrm{O}_{2}$ (Havir and Mchale, 1989). The decrease in absorbance by $\mathrm{H}_{2} \mathrm{O}_{2}$ consumption was measured for the two minutes of reaction at $240 \mathrm{~nm}$ at a temperature of $25^{\circ} \mathrm{C}$. Enzyme activity was calculated using the molar extinction coefficient of $36 \mathrm{M}^{-1} \cdot \mathrm{cm}^{-1}$ and expressed in $\mu \mathrm{mol}$ of $\mathrm{H}_{2} \mathrm{O}_{2} \mathrm{~min}^{-1} \cdot \mathrm{mg}^{-1}$ protein (Anderson et al., 1995).

Peroxidase (POX): determined by addition of $50 \mu \mathrm{L}$ of crude enzyme extract to $2.95 \mathrm{~mL}$ of reaction mixture consisting of $25 \mathrm{mM}$ of potassium phosphate, $\mathrm{pH} \mathrm{6.8,20} \mathrm{mM} \mathrm{of} \mathrm{pyrogallol,} \mathrm{and} 20 \mathrm{mM} \mathrm{H}_{2} \mathrm{O}_{2}$ (Kar and Mishra, 1976). Production of purpurogallin was determined by the increase in absorbance at $420 \mathrm{~nm}$ at $25{ }^{\circ} \mathrm{C}$ up to the second minute of the reaction. Enzyme activity was calculated using the molar extinction coefficient of $2.47 \mathrm{mM}^{-1} . \mathrm{cm}^{-1}$ (Maehley and Chance, 1955).

The protein concentration for all the samples and biochemical analyses was determined by the Bradford (1976) method, using the standard curve constructed with bovine serum albumin, from 2.5 to $50 \mu \mathrm{g}$ of protein.

Statistical analysis: a completely randomized experimental design was used. Analysis of variance was performed on all the data. The mean values of germination percentage were compared by Tukey's test at $5 \%$ probability. Polynomial regression equations were fitted for enzyme activity and electrical conductivity. All analyses were performed with the assistance of the Sisvar 5.6 statistical program (Ferreira, 2011). 


\section{RESULTS AND DISCUSSION}

Temperatures from 25 to $35{ }^{\circ} \mathrm{C}$ most stimulated the germination process of $D$. spruceana seeds. The germination percentage was similar in this temperature range (Figure $1 \mathrm{~A}$ ), with maximum levels at 25 and $30{ }^{\circ} \mathrm{C}$. For the GSI, the temperature of $30^{\circ} \mathrm{C}$ led to the highest germination speed, with a mean of 6.7 seeds germinated per day (Figure 1B).

Temperatures of 20 and $40{ }^{\circ} \mathrm{C}$ had a negative effect on the germination process, especially for germination percentage (Figure $1 \mathrm{~A}$ ). The temperature of $40^{\circ} \mathrm{C}$ accelerated germination compared to $20^{\circ} \mathrm{C}$ (Figure $1 \mathrm{~B}$ ). This was likely due to accelerated metabolic activity at this temperature, since it benefits the most vigorous seeds of the seed lot. Overall germination was clearly lower than at the other temperatures.

Brancalion et al. (2010) found that temperatures of 25 and $30{ }^{\circ} \mathrm{C}$ are optimal for germination, and the latter temperature is most suitable for Amazon species. The temperature of $20^{\circ} \mathrm{C}$ is sub-optimal for the species of this study, in accordance with lower germination responses. The seeds analyzed in this study were collected from a tropical region with mean annual temperature from $20^{\circ} \mathrm{C}$ minimum to $36^{\circ} \mathrm{C}$ maximum (Viana et al., 2016). The optimal temperature range found for $D$. Spruceana, $25-35^{\circ} \mathrm{C}$, would be a possible explanation for the germination performance obtained in this study, considering the similarity between the temperature range of the location of occurrence of the species and that of the germination test.

SOD activity exhibits a tendency of stability at $20^{\circ} \mathrm{C}$ during the imbibition period. Continuous decreases occurred in SOD activity at the other temperatures from time zero on, remaining constant arriving at 72 hours of imbibition; at 96 hours of imbibition, there is a more accentuated decrease (Figure 2).

The results for the SOD enzyme would indicate that even though SOD is pre-formed in a preventive manner or formed during the fruit and seed development phase, it would not act in a differentiated manner in relation to the environmental stimulus during germination. In Melanoxylum brauna seeds (Flores et al., 2014b), similar results were observed, in which SOD activity under the temperatures of 25,30 , and $40^{\circ} \mathrm{C}$ decreased from time zero on and remained constant throughout the germination period.

The stability of SOD activity at $20^{\circ} \mathrm{C}$ shows this enzyme to be indifferent at low temperature, likely because $20^{\circ} \mathrm{C}$ is not a thermal condition that stimulates the action of this enzyme in the seeds of this study. The decline in activity at 96 hours in the 25 to $35^{\circ} \mathrm{C}$ temperature range could be the result of reduction in superoxide concentration, both by activity of the enzyme and by the action of other antioxidant systems.
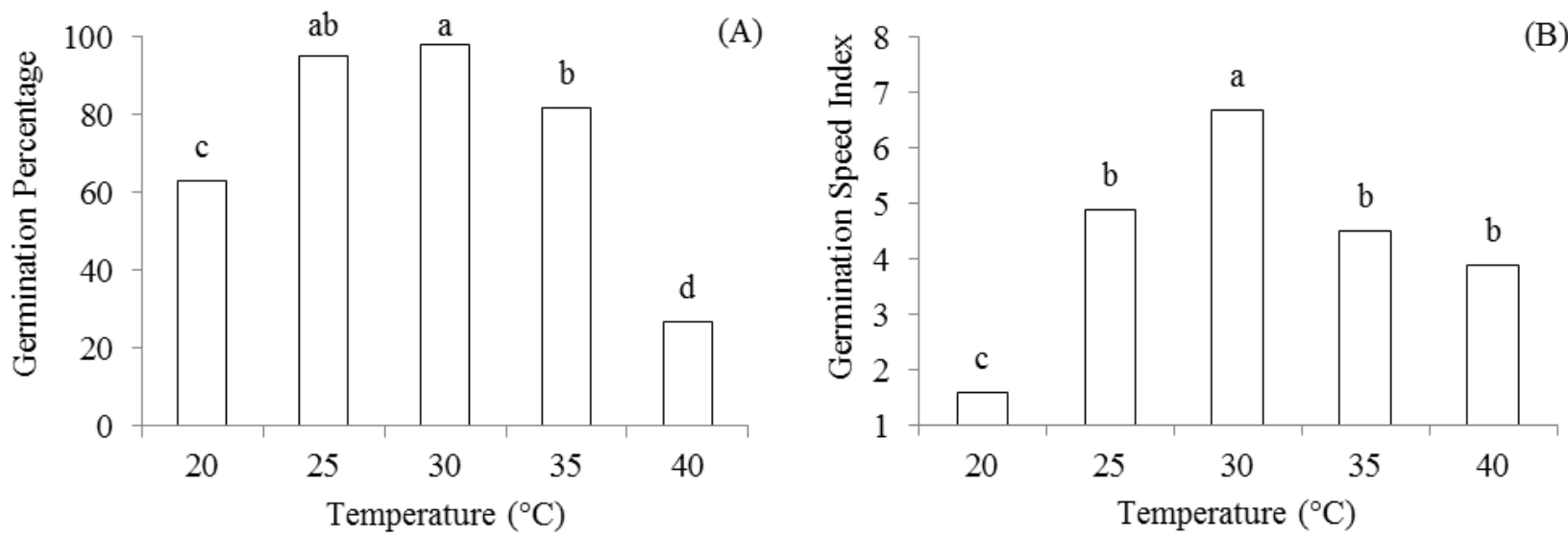

Mean values followed by the same letter do not differ from each other by Tukey's test at $5 \%$.

Figure 1. Germination percentage (A) and germination speed index (B) of Dalbergia spruceana Benth. seeds under different temperatures. 


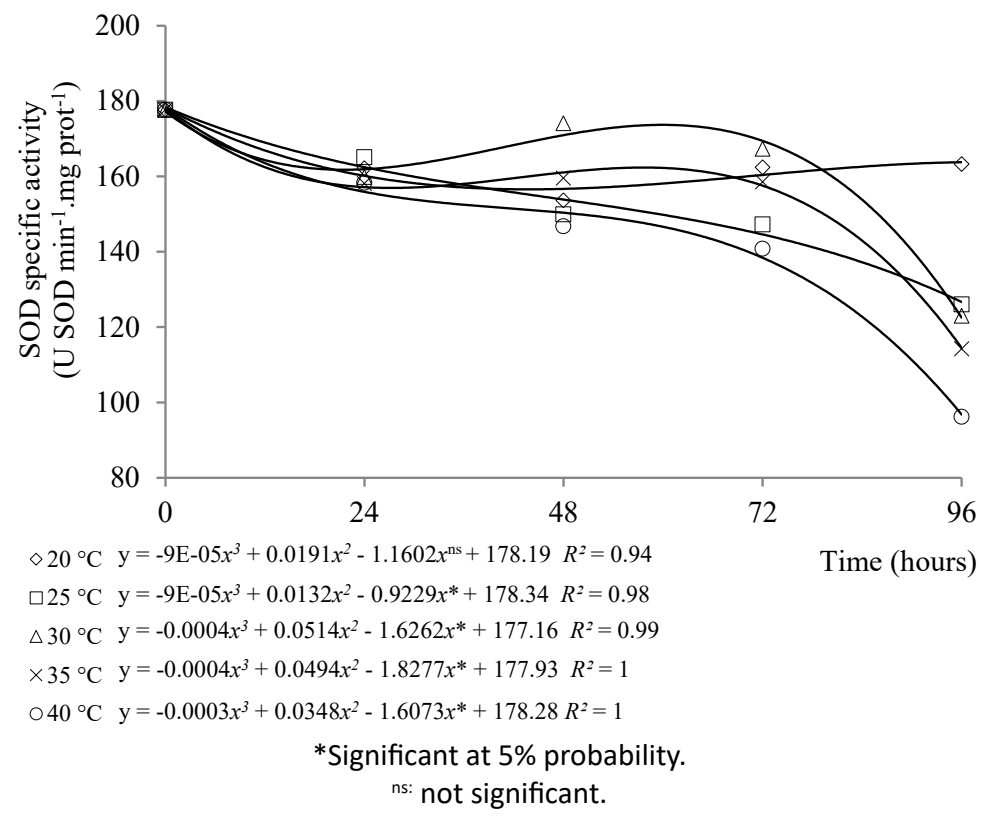

Figure 2. Activity of the superoxide dismutase (SOD) enzyme in Dalbergia spruceana Benth. embryos during the germination period under different temperatures.

The ideal temperature for structural integrity and activity of most of the enzymes is in the range of $30-45{ }^{\circ} \mathrm{C}$ (Hasanuzzaman et al., 2013). However, exposure to $40{ }^{\circ} \mathrm{C}$ for a period of 96 hours compromises structural integrity and SOD activity in $D$. spruceana seeds. Reduction in antioxidant enzyme activity can also occur due to accumulation of ROS up to toxic levels (Kong et al., 2014).

Hydrogen peroxide $\left(\mathrm{H}_{2} \mathrm{O}_{2}\right)$ is generated from disproportionation of the superoxide radical by the action of SOD (Matos et al., 2014). SOD activity in the seeds of this study led to increases in the $\mathrm{H}_{2} \mathrm{O}_{2}$ concentrations in the cells, regardless of temperature. And in coordinated action with the other antioxidant mechanisms, it is likely that the hydrogen peroxide level remained at concentrations that did not affect metabolism.

In $D$. spruceana seeds, CAT proved to be an inductive enzyme, being formed the beginning of the germination process (Figure $3 \mathrm{~A}$ ). POX exhibited activity similar to CAT in relation to temperature and imbibition time, although at clearly lower values (Figure $3 \mathrm{~B}$ ). The highest peaks of activity for the two enzymes occurred at 72 hours of imbibition at the temperatures of 25 and $40{ }^{\circ} \mathrm{C}$, while at 20,30 , and $35^{\circ} \mathrm{C}$, the greatest activity occurred at 96 hours, with significant differences in both periods in relation to the initial time. It should be noted that in spite of the damaging effect of the temperature of $40{ }^{\circ} \mathrm{C}$ on germination, CAT activity increased slowly until reaching the values near those of $25^{\circ} \mathrm{C}$. In overall analysis, it can be supposed that the hydrogen peroxide level increased and there was a need for activity of the enzymes to prevent concentrations that would be damaging to cells.

The actions of catalase and of peroxidase obtained in this study indicate different metabolic pathways of $\mathrm{H}_{2} \mathrm{O}_{2}$ in the cells of $D$. spruceana seeds. CAT is important in removal of peroxide generated in the peroxisomes by the oxidases involved in beta oxidation of fatty acids (Saisanthosh et al., 2018). The POXs are mainly located in the cell wall and in the vacuole, and their activity can also be used as a biochemical marker of stress resulting from biotic and abiotic factors (Locato et al., 2010). These two enzymes act in the removal of excessive hydrogen peroxide in the cell produced by SOD (Sharma et al., 2012). It is noteworthy that when the activity of one enzyme is reduced, other enzymes increase their activity (or other non-enzymatic mechanisms are activated) so as to ensure repair of oxidative damage.

CAT activity is effective at relatively high concentrations of $\mathrm{H}_{2} \mathrm{O}_{2}$ due to the low affinity of CAT to peroxide (Sharma et al., 2012). This characteristic implies that seeds must remain under stressful conditions to induce acceleration of the oxidative process and activation of antioxidant enzyme activity of CAT in D. spruceana seeds. In addition, ROSs 


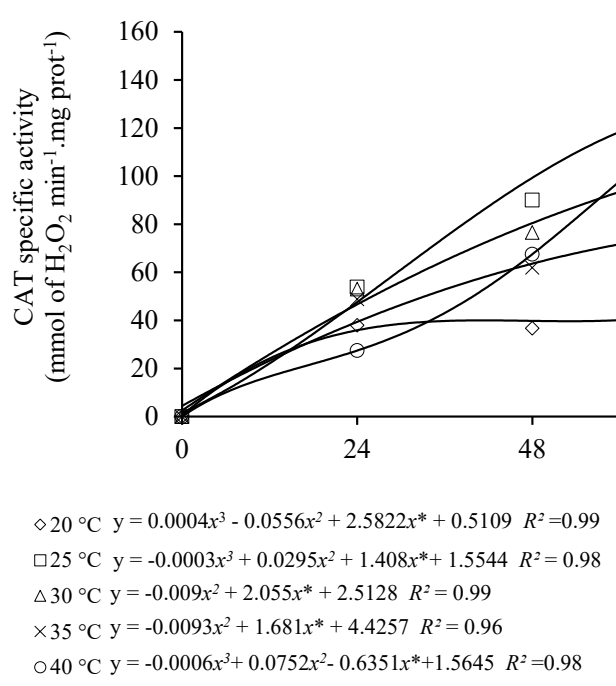

(A)

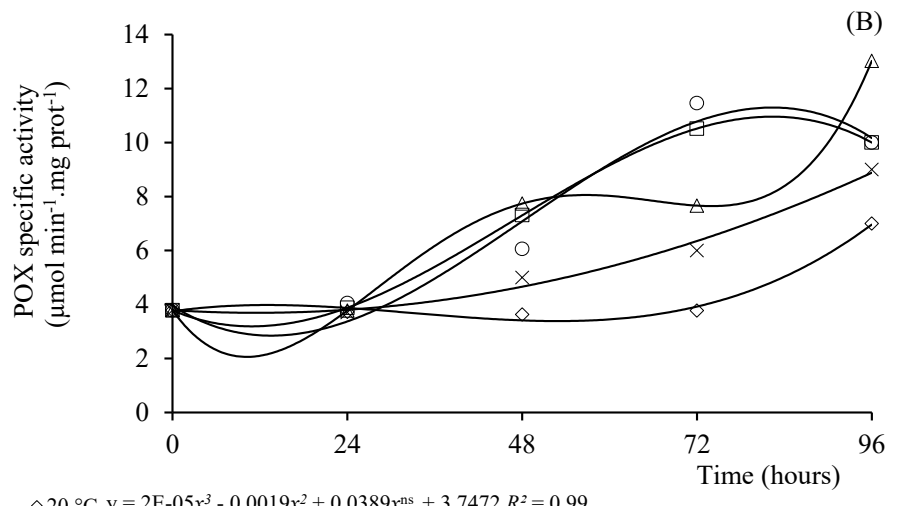

$\diamond 20^{\circ} \mathrm{C} y=2 \mathrm{E}-05 x^{3}-0.0019 x^{2}+0.0389 x^{\text {ns }}+3.7472 R^{2}=0.99$

$\square 25^{\circ} \mathrm{C} \mathrm{y}=-4 \mathrm{E}-05 x^{3}+0.006 x^{2}-0.1143 x^{*}+3.7823 R^{2}=1$

$\triangle 30^{\circ} \mathrm{C}$ y $=2 \mathrm{E}-06 x^{4}-0.0004 x^{3}+0.0243 x^{2}-0.3766 x^{*}+3.7837 R^{2}=1$

$\times 35^{\circ} \mathrm{C} \mathrm{y}=0.0007 x^{2}-0.0168 x^{*}+3.7884 R^{2}=0.92$

$040^{\circ} \mathrm{C} y=-5 \mathrm{E}-05 x^{3}+0.0075 x^{2}-0.1734 x^{*}+3.9539 R^{2}=0.95$

*Significant at $5 \%$ probability.

ns: not significant.

Figure 3. Activity of the catalase (CAT) and peroxidase (POX) enzymes in Dalbergia spruceana Benth. embryos during the germination period at different temperatures.

produced in seeds in the dry state may become effective as messengers or transmitters of signals only when the seeds are hydrated, that is, during germination (Bailly et al., 2008).

The increase in activity at 25 and $30{ }^{\circ} \mathrm{C}$ can be explained by greater metabolic activity at these temperatures. It should be recognized that greater induction of root emergence and speed of the process at optimal temperatures leads to production of ROSs in the cell as a natural by-product of mitochondrial respiration (Flores et al., 2014b). Bailly (2004) showed that root emergence occurs at the time in which the ROS concentration reaches a stationary state. In this context, the lower increase in enzyme activity at $20^{\circ} \mathrm{C}$ may be a result of lower metabolic activity under that condition, based on the low percentage of germination.

Thus, an increase in antioxidant enzyme activity during germination of $D$. spruceana seeds may express an oxidative state of the cells in disequilibrium. This has direct implications on the need for strict control between production of toxic oxygen metabolites and their suppression by enzyme activity before oxidative damage can be established and compromise the metabolic efficiency of the seeds.

At $35^{\circ} \mathrm{C}$ there was a discreet increase in peroxidase activity (Figure 3 ) over the germination period, in which the levels of activity of the two enzymes were satisfactory, with a probable effect on cell detoxification. An interesting signal of the protective mechanism of the CAT and POX is shown through the evolution of their activity over the time of imbibition. The production of the enzymes increased with imbibition, indicating antioxidant enzyme participation to maintain redox equilibrium in the germination process.

Maintaining seeds at $40{ }^{\circ} \mathrm{C}$ can lead to a chain of events that begins with lipid peroxidation and later rupture of the cell membrane (Santos et al., 2017). The increase in temperature stimulates an increase in respiration and consequent production of ROSs on a greater scale in the mitochondria. This would then bring about changes in cell membranes, reduce ATP production, and consequently lead to seed death (Matos et al., 2014). Among other deleterious aspects, ROSs harm seeds due to their high reactivity with biomolecules, including proteins, sugars, lipids, and nucleic acids (Bailly et al., 2008). All these biomolecules are essential for supplying energy used in the germination process.

The destructuration of the plasmatic membrane results in leakage of exudates to the environment (Santos et al., 2017). The most important event during imbibition is probably reorganization of the membrane, given that it occurs before other events and is a pre-condition for most of the cell processes (Yu et al., 2015). 
Increasing leakage of electrolytes indicates loss of the semipermeability of the cell membranes in $D$. spruceana seeds at higher temperatures, with a maximum peak of release at $40{ }^{\circ} \mathrm{C}$ (Figure 4). The damage caused by high temperature is clear and can be detected at 48 hours.

Most of the leakage of ions occurs during the initial phase of seed imbibition (Yu et al., 2015). Therefore, the membranes must reorganize themselves to restore normal function and interrupt the leakage of cell components essential for metabolism (Matos et al., 2015). Thus, we presume that for the seeds in this study, high temperature conditions made this reorganization impossible, in a manner similar to that observed in other forest species (Flores et al., 2014a; Matos et al., 2015; Santos et al., 2017).

The results of electrical conductivity, obtained for the seeds under the temperatures of 25 and $30^{\circ} \mathrm{C}$ are compatible with the germination data. Test results indicate that at the temperatures near that considered optimal for germination of the species, phospholipids change from the gel phase to the liquid phase, which establishes the semipermeability of the membranes (Hasanuzzaman et al., 2013). Semipermeability is necessary for operation of cell membranes, also according to results obtained by Flores et al. (2014a) in Melanoxylon brauna seeds.

In the case of seeds under the lowest temperature, the low values of electrical conductivity lead to the supposition that the melting temperature of the components of the phospholipids was reached, impeding leakage of electrolytes (Narayanan, 2018). This supposition is supported by the increase in electrical conductivity when the temperature is increased to 25 and $30{ }^{\circ} \mathrm{C}$, in which an increase in the difference occurs between the ambient temperature and that of melting of fatty acids of the phospholipids. In addition, seeds sensitive to cooling may exhibit reduction in the expression of genes that regulate the number of aquaporins or their activity, which affects the water absorption rate of the seeds (Reis et al., 2020). This may have led to reduction in the germination of the seeds of this study at the lowest temperature.

Heat stress in the $D$. spruceana seeds generally became clear at $40^{\circ} \mathrm{C}$ by greater reduction in germination percentage, increase in the values of electrical conductivity, and changes in the activity of the antioxidant enzymes, in a negative manner in SOD at the longest exposure time. These results manifest oxidative processes probably related to greater speed of the deterioration process by the respiratory intensity of the seeds exposed to this temperature (Marini et al., 2012).

The pattern of activity presented by the coordinated action of the antioxidant enzymes of this study therefore reflects the need to preserve the redox equilibrium of the $D$. spruceana seeds in stressful heat situations. Although the ability to withstand heat stress for long periods of time depends on complex stress tolerance mechanisms, the results of this study suggest that $D$. spruceana seeds maintain cell homeostasis in the 25 to $35^{\circ} \mathrm{C}$ temperature range.

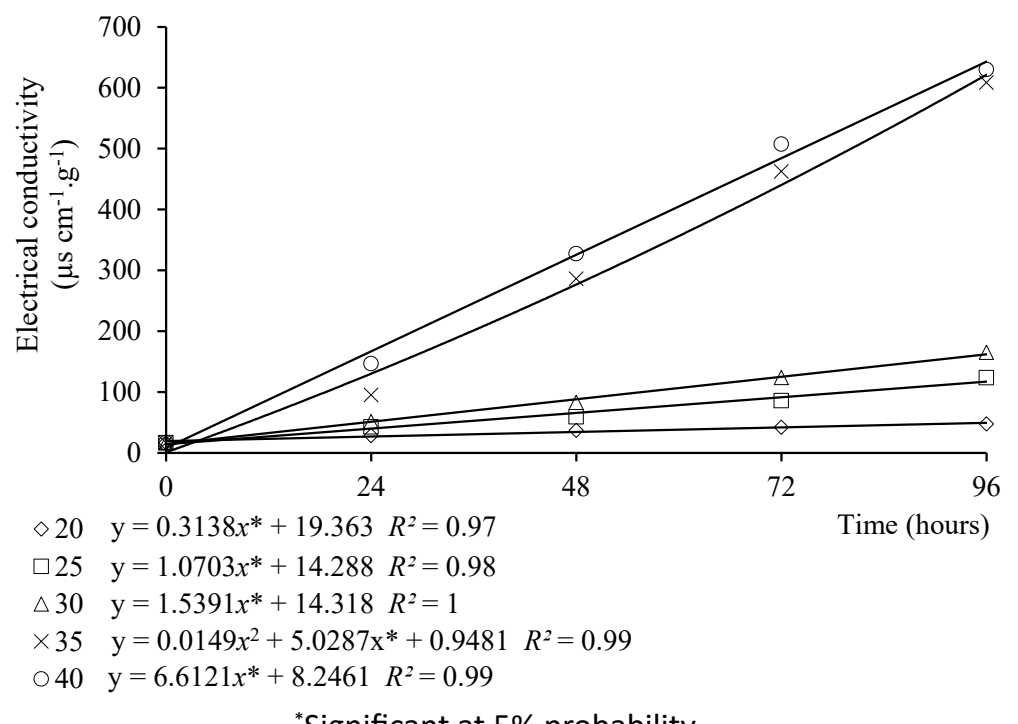

*Significant at $5 \%$ probability.

Figure 4. Electrical conductivity in accordance with temperature and exposure time of Dalbergia spruceana Benth. seeds. 


\section{CONCLUSIONS}

The temperatures of 25,30 , and $35^{\circ} \mathrm{C}$ stimulate the seed germination process, whereas $40{ }^{\circ} \mathrm{C}$ has deleterious effects on metabolism. SOD activity proves to be indifferent to variations in temperature, and the levels of CAT and POX activity do not allow them to be established as indicators of heat stress. The semipermeability of the cell membranes is dependent on temperature and not on the possible effects of the ROSs.

\section{REFERENCES}

ANDERSON, M.D.; PRASAD, T.K.; STEWART, C.R. Changes in isozyme profiles of catalase, peroxidase, and glutathione reductase during acclimation to chilling in mesocotylus of maize seedlings. Plant Physiology, v.109, p.1247-1257, 1995. https://doi.org/10.1104/ pp.109.4.1247

BAILLY, C. Active oxygen species and antioxidants in seed biology. Seed Science Research, v.14, n.1, p.93-107, 2004. Doi: 10.1079/ SSR2004159

BAILLY, C.; MAAROUF-BOUTEAU, H.E.; CORBINEAU, F. From intracellular signaling networks to cell death: the dual role of reactive oxygen species in seed physiology. Comptes Rendus Biologies, v.331, n.1, p.806-814, 2008. doi:10.1016/j.crvi.2008.07.022

BEAUCHAMP, C.; FRIDOVICH, I. Superoxide dismutase improved as says and as say applicable to acrylamide gels. Analytical Biochemistry, v.44, n.1, p.276-287, 1971. https://doi.org/10.1016/0003-2697(71)90370-8

BRADFORD, M.M. A rapid and sensitive method for the quantification of microgram quantities of proteins utilizing the principle of protein-dye binding. Analytical Biochemistry, v.72, n.1-2, p. 248-254, 1976. https://doi.org/10.1016/0003-2697(76)90527-3

BRANCALION, P.H.S.; COELHO, A.D.L.; RODRIGUES, R.R. Temperatura ótima de germinação de sementes de espécies arbóreas brasileiras. Journal of Seed Science, v.32, n.4, p.15-21, 2010. https://www.scielo.br/pdf/rbs/v32n4/02.pdf

BRASIL. Ministério da Agricultura, Pecuária e Abastecimento. Regras para análise de sementes. Ministério da Agricultura, Pecuária e Abastecimento. Secretaria de Defesa Agropecuária. Brasília: MAPA/ACS, 2009. 395p. https://www.gov.br/agricultura/pt-br/ assuntos/insumos-agropecuarios/arquivos-publicacoes-insumos/2946_regras_analise_sementes.pdf

CHANCE, B.; MAEHLEY, A.C. Assay of catalases and peroxidases. Methods in Enzymology, v.2, p.764-775, 1955. Doi: 10.1016/S0076$6879(55) 02300-8$

DEL LONGO, O.T.; GONZÁLEZ, C.A.; PASTORI, G.M.; TRIPPI, V.S. Antioxidant defenses under hyperoxygenic and hyperosmotic conditions in leaves of two lines of maize with differential sensitivity to drought. Plant Cell Physiology, v.37, n.7, p.1023-1028, 1993. https://doi.org/10.1093/oxfordjournals.pcp.a078515

FERREIRA, D.F. SISVAR: a computer statistical analysis system. Ciência e Agrotecnologia, v.35, n.6, p.1039-1042, 2011. https://doi. org/10.1590/S1413-70542011000600001

FLORES, A.V.; BORGES, E.E.L.; GUIMARÃES, V.M.; ATAÍDE, G.M.; VINÍCIUS, O.C.R. Germinação de sementes de Melanoxylon brauna Schott em diferentes temperaturas. Revista Árvore, v.8, n.6, p.1147-1154, 2014a. https://doi.org/10.1590/S010067622014000600019

FLORES, A.V.; BORGES, E.E.L.; GUIMARÃES, V.M.; GONÇALVES, J.F.C.; ATAÍDE, G.M.; BARROS, D.P. Atividade enzimática durante a germinação de sementes de Melanoxylon brauna Schott sob diferentes temperaturas. Cerne, v.20, n.3, p.401-408, 2014b. http:// dx.doi.org/10.1590/01047760201420031399

GAMA, J.R.V.; PINHEIRO, J.C. Inventário florestal para adequação ambiental da fazenda Santa Rita, município de Santarém, Estado do Pará. Floresta, v.40, n.3, p.585-592, 2010. Doi: http://dx.doi.org/10.5380/rf.v40i3.18920

GIANNOPOLITIS, C.N.; RIES, S.K. Superoxide dismutases: purification and quantitative relationship with water-soluble protein in seedlings. Plant Physiology, v.59, n.2, p.315-318, 1977. Doi: 10.1104 / pp.59.2.315

GONÇALVES, D.C.M.; GAMA, J.R.V.; OLIVEIRA, F.A.; OLIVEIRA-JUNIOR, R.C.; ARAÚJO, G.C.; ALMEIDA, L.S. Aspectos mercadológicos dos produtos não madeireiros na economia de Santarém-Pará, Brasil. Floresta e Ambiente, v.19, n.1, p.9-16, 2012. http://dx.doi. org/10.4322/floram.2012.002 
HASANUZZAMAN, M.; NAHAR, K.; FUJITA, M. Extreme temperature responses, oxidative stress and antioxidant defense in plants. In: Abiotic stress - plant responses and applications in agriculture. Londres: IntechOpen, 2013. p.169-205. http://dx.doi. org/10.5772/54833

HAVIR, E.; McHALE, N.A. A regulation of catalase activity in leaves of Nicotiana sylvestris by high $\mathrm{CO}_{2}$. Plant Physiology, v.89, n.3, p.952-957, 1989. Doi: 10.1104 / pp.89.3.952

KAR, M.; MISHRA, D. Catalase, peroxidase, and polyphenoloxidase activities during rice leaf senescence. Physiology Plantarum, v.57, p.315-319, 1976 .

KONG, Q.; MAO, P.S.; YU, X.D.; XIA, F.S. Physiological changes in oat seeds aged at different moisture contents. Seed Science and Technology, v.42, p.190-201, 2014. https://doi.org/10.15258/sst.2014.42.2.08

LOCATO, V.; PINTO, M.C.; PARADISO, A.; GARA, L. Reactive oxygen species and ascorbate glutathione interplay in signaling and stress responses. In: GUPTA, S.D. Reactive oxygen species and antioxidants in higher plants. Enfield: Science Publishers, 2010. p.4564. https://books.google.com.br/books?hl=pt-BR\&lr=\&id=C4HRBQAAQBAJ\&oi=fnd\&pg=PP1\&ots=sigTVHfiAA\&sig=N3bWBiotwL oVIBYJEzqIEkLrgdY\&redir_esc=y\#v=onepage\&q\&f=false

MAGUIRE, J.D. Speed of germination and in selection and evaluation from seeding emergence and vigor. Crop Science, v.2, n.2, p.176-177, 1962. https://acsess.onlinelibrary.wiley.com/doi/epdf/10.2135/cropsci1962.0011183X000200020033x

MARINI, P.; MORAES, C.L.; MARINI, N.; MORAES, D.M.; AMARANTE, L. Alterações fisiológicas e bioquímicas em sementes de arroz submetidas ao estresse térmico. Revista Ciência Agronômica, v.43, n.4, p.722-730, 2012. https://www.scielo.br/pdf/rca/v43n4/ v43n4a14

MATOS, A.C.B.; BORGES, E.E.L.; SEKITA, M.C. Production of reactive oxygen species in Dalbergia nigra seeds under thermal stress. Journal of Seed Science, v.36, n.3, 2014. https://doi.org/10.1590/2317-1545v36n3973

MATOS, A.C.B.; BORGES, E.E.L.; SILVA, L.J. Fisiologia da germinação de sementes de Dalbergia nigra (Vell.) Allemão ex Benth. sob diferentes temperaturas e tempos de exposição. Revista Árvore, v.39, n.1, p.115-125, 2015. https://doi.org/10.1590/010067622015000100011

NARAYANAN, S. Effects of high temperature stress and traits associated with tolerance in wheat. Journal of Science, v.2, n.3, p.177186, 2018. Doi: 10.15406/oajs.2018.02.00067

PEIXOTO, P.H.P.; CAMBRAIA, J.; SANT'ANNA, R.; MOSQUIN, P.R.; MOREIRA, M.A. Aluminium effects on lipid peroxidation and on the activities of enzymes of oxidative metabolism in sorghum. Revista Brasileira de Fisiologia Vegetal, v.11, n.3, p.137-143, 1999. https://www.researchgate.net/publication/267338431_

REIS, L.P.; BORGES, E.E.L.; SOUZA, G.A.; BRITO, D.S. Relationships between substrate and the mobilization of reserve with temperature during seed germination of Ormosia coarctata Jack. Journal of Seed Science, v.42, n.1, 2020. http://dx.doi.org/10.1590/23171545v42223509

RIBEIRO, R.C.; MATIAS, J.R.; PELACANI, C.R.; DANTAS, B.F. Activity of antioxidant enzymes and proline accumulation in Erythrina velutina Willd. seeds subjected to abiotic stresses during germination. Journal of Seed Science, v.36, n.2, p.231-239, 2014. https:// doi.org/10.1590/2317-1545v32n2956

RUELLAND, E.; ZACHOWSKI, A. How plants feel temperature. Environmental and Experimental Botany, v.69, n.3, p.255-232, 2010. Doi: 10.1016 / j.envexpbot.2010.05.011

SAISANTHOSH, K.; SUMALATHA, G.M.; SHUBA, A.C.; KOMALA, N.T.; BIRADAR PATIL, N.K. Role of enzymatic antioxidants defense system in seeds. International Journal of Current Microbiology and Applied Sciences, v.7, n.1, p.584-594, 2018. https://www.ijcmas. com/special/7/Kartoori\%20Saisanthosh,\%20et\%20al.pdf

SANTOS, M.M.; BORGES, E.E.L.; ATAÍDE, G.M.; SOUZA, G.A. Germination of seeds of Melanoxylon brauna Schott. under heat stress: production of reactive oxygen species and antioxidant activity. Forests, v.8, n.11, 2017. https://doi.org/10.3390/f8110405

SHARMA, P.; JHA, A.B; DUBEY, R.S; PESSARAKLI, M. Reactive oxygen species, oxidative damage, and antioxidative defense mechanism in plants under stressful conditions. Journal of Botany, 2012. https://doi.org/10.1155/2012/217037

SOUZA, L.A.G. Guia da biodiversidade de Fabaceae do Alto Rio Negro. 2012. 118p. Available at: https://www.inpa.gov.br/arquivos/ livro_fronteiras/Pesquisadores/10-Luiz-Augusto/Guia\%20Fabaceae\%20-\%20Livro.pdf. Accessed on: April 27, 2020. 
VIANA, P.L.; MOTA, N.F.O.; GIL, A.S.B.; SALINO, A.; ZAPPI, D.C.; HARLEY, R.M.; ILKIU-BORGES, A.L.; SECCO, R.S.; ALMEIDA, T.E.; WATANABE, M.T.C.; SANTOS, J.U.M.; TROVÓ, M.; MAURITY, C.; GIULIETTI, A.M. Flora of the cangas of the Serra dos Carajás, Pará, Brazil: history, study area and methodology. Rodriguésia, v.67, n.5, p.1107-1124, 2016. Doi: 10.1590/2175-7860201667501

YU, X.; LI, A.; LI, W. How membranes organize during seed germination: three patterns of dynamic lipid remodelling define chilling resistance and affect plastid biogenesis. Plant Cell Environment, v.38, n.7, p.1391-1403, 2015. Doi: 10.1111/pce.12494

ZHENG, G.; TIAN, B.; ZHANG, F.; TAO, F.; LI, W. Plant adaptation to frequent alterations between high and low temperatures: remodelling of membrane lipids and maintenance of unsaturation levels. Plant Cell and Environment, v.34, n.9, p.1431-1442, 2011. https://doi.org/10.1111/j.1365-3040.2011.02341.x use, distribution, and reproduction in any medium, provided the original work is properly cited. 